\title{
Growth Responses of Some Bacterial Isolates to Some Environmental Parameters
}

\author{
Esther Aanuoluwa Ekundayo ${ }^{1^{*}}$, Olayinka Temitayo Ogunmefun ${ }^{2}$, Ijeoma Nwaefere Oguike ${ }^{2}$, \\ Fred Coolborn Akharaiyi' ${ }^{3}$, Oluwakemi Sola Asoso²
}

${ }^{1}$ Department of Microbiology, The Federal University of Technology, Akure, Nigeria

${ }^{2}$ Department of Biological Sciences, AfeBabalola University, Ado-Ekiti, Nigeria

${ }^{3}$ Department of Microbiology, Edo University, Iyhamo, Nigeria

Email: *esttydayo2010@yahoo.com

How to cite this paper: Ekundayo, E.A., Ogunmefun, O.T., Oguike, I.N., Akharaiyi, F.C. and Asoso, O.S. (2018) Growth Responses of Some Bacterial Isolates to Some Environmental Parameters. Advances in Bioscience and Biotechnology, 9, 561-570. https://doi.org/10.4236/abb.2018.911039

Received: October 3, 2017

Accepted: November 13, 2018

Published: November 16, 2018

Copyright $\odot 2018$ by authors and Scientific Research Publishing Inc. This work is licensed under the Creative Commons Attribution International License (CC BY 4.0).

http://creativecommons.org/licenses/by/4.0/

\begin{abstract}
This study was carried out to investigate the antimicrobial activities of bacterial isolates of maize against plant pathogens as well as their growth responses to some environmental parameters. Twenty four bacterial isolates were obtained from maize plants collected from the Department of Biological Sciences, AfeBabalola University, Ado-Ekiti. The isolates were characterized by their biochemical and physiological characteristics and were identified as Kurthiazopfu, Morganellamorganic, Rhodococcusequi, Bacillus subtilis, Catabaterhongkongensis, Brevibacteriumotitidis, Lactobacillus coleohominis, Staphylococcus aureus, Propionibacterium acnes among others. Their responses to different $\mathrm{NaCl}$ concentrations, sugars, temperature as well as antibiotics were determined. Most of the isolates were able to withstand various environmental parameters in which they were subjected to. Also, eight isolates were able to ferment sucrose. The bacterial isolates showed a degree of resistance to the antibiotics tested. There was a high prevalence of multidrug resistant bacteria showing resistance to 3 - 8 drugs. The antagonistic effect of the bacterial isolates against selected fungi was determined. None of the isolates showed antagonistic potential against the fungal pathogens. However, the supposed antagonistic bacterial species can be genetically modified to produce secondary metabolites that will result in biocontrol.
\end{abstract}

\section{Keywords}

Maize Plants, Growth Responses, Bacterial Isolates, Secondary Metabolites, Biocontrol

\section{Introduction}

Plant diseases are threat to world agriculture and general food security of which 
fungi cause about $75 \%$ of the diseases [1]. Significant yield losses due to pathogens' attack have been shown to occur in most agricultural and horticultural crops [2] [3]. About 25 million NGN was lost in Nigeria due to black pod disease which occurred in 1995 [4] [5].

Chemicals such as fertilizers and pesticides including fungicide have been used in the past in controlling plant diseases leading to increase productivity [3]. However, due to the negative effects of these chemicals on the environment and non target organisms, alternatives have been sought in controlling plant diseases and these alternatives include the use of microorganisms among others [3] [6]. Bacteria have been used as biological control agents for several decades [7]. Different plant associated bacteria often associated with and their metabolites have been identified as important contributors to the biological control of plant diseases [8]. Their mode of action has been linked to antibiotics such bacteria produce during their stationary phase. For example, biocontrol strains of Pseudomonas are known to synthesize phenazine carboxylic acid, pyrronitril and pyoluterin [9] [10] [11] [12]. Also, Bacillus species which are often associated with agricultural systems are known to be involved in biocontrol since they are capable of producing antibiotics [13] [14] [15] [16].

Growth of microorganisms is influenced by various environmental conditions and the effect may either favor their growth or retard their multiplication rate and the synthesis of different metabolites [17]. Environmental parameters such as temperature, aeration, nutrients or $\mathrm{pH}$ can become limiting factors for $\mathrm{mi}$ croorganism's survival. Biocontrol agents have been shown to be sensitive to varying environmental conditions such as temperature, $\mathrm{pH}$ and moisture content and these factors affect their usefulness. This current investigation therefore sought to determine the responses of maize associated bacteria to some environmental conditions as well as their antimicrobial properties.

\section{Materials and Methods}

\subsection{Collection of Samples}

Twenty four unidentified bacterial isolates were collected from the Microbiology unit of AfeBabalola University, Ado-Ekiti. The isolates were isolated from different parts of maize plants. Ralstoniasolanacearum strain Ogbomoso, Ralstoniasolanacearum strain Saki, Ralstoniasolanacearum strain Nihort, Fusarium equiseti strain Saki, Trichoderma viride from the Department of Biological Sciences, AfeBabalola University Ado-Ekiti, and Pseudomonas spp. were obtained from Ibadan. Also, a fungicide; Mancozeb was collected from AfeBabalola University Ado-Ekiti, Ekiti Farm.

\subsection{Characterization of the Bacterial Isolates}

The unidentified bacterial isolates were identified based on their morphological, cultural and biochemical characteristics after Gram staining according to standard 
procedures [18].

\subsection{Growth Characteristics of the Bacterial Isolates at Different Temperature}

The test was done to identify organisms that can grow at different temperature $\left(4^{\circ} \mathrm{C}, 25^{\circ} \mathrm{C}, 37^{\circ} \mathrm{C}, 50^{\circ} \mathrm{C}\right)$ for $24 \mathrm{~h}$ on nutrient agar plates. Presence of growth showed the organisms can tolerate the temperature [19].

\subsection{Growth Characteristics of the Bacterial Isolates at Different $\mathrm{pH}$}

The test was done to identify organisms that can grow at different $\mathrm{pH}(2,4,6,8$, 10). Nutrient broth ( $\mathrm{Lab} \mathrm{M}$ ) was prepared according to the manufacturer's procedure and their $\mathrm{pH}$ was adjusted to 2, 4, 6, 8 and 10 using Cacodylate and Succinic acid buffer solutions (brand name). The prepared broth were inoculated with the organisms and incubated at $37^{\circ} \mathrm{C}$ for $24 \mathrm{~h}$. The presence of growth was determined by the absorbance using the SP 600 Spectrophotometer (brand name) at wavelength of $600 \mathrm{~nm}$.

\subsection{Growth Characteristics of the Bacterial Isolates at Different Concentrations of $\mathrm{NaCl}$}

The test was done to identify organisms that can grow at different concentration of $\mathrm{NaCl}(1 \%, 2 \%$, and $3 \%)$. Nutrient agar was prepared according to the manufacturer's procedure and the $\mathrm{NaCl}$ was added to the media. The prepared agar was inoculated with the organisms and incubated at $37^{\circ} \mathrm{C}$ for $24 \mathrm{~h}$. The presence of growth shows the organisms can utilize the salt and survive high salinity [19].

\subsection{Antibiotic Susceptibility Test}

The antimicrobial susceptibility testing was done using agar disk diffusion method. Fresh isolates were suspended in peptone broth in comparison to 0.5 McFarland standards. Each of the isolates was inoculated onto the surface of a sterile Mueller Hinton Agar plates using sterile swab in order to ensure even distribution while streaking. The plates were allowed to dry for 10 minutes and the antibiotic disc were placed on the surface of the agar plates using a sterile forceps. The plates were then inverted and incubated for $24 \mathrm{~h}$ at $37^{\circ} \mathrm{C}$. The antimicrobial disc includes the Gram negative disc which serves as a positive control for Gram negative organisms; Augmentin (30 $\mu \mathrm{g})$, Ofloxacin $(5 \mu \mathrm{g})$, Gentamicin $(10 \mu \mathrm{g})$, Nalidixic acid $(30 \mu \mathrm{g})$, Nitrofuratoin $(200 \mu \mathrm{g})$, Cotrimoxazole $(25 \mu \mathrm{g})$, Amoxycillin $(25 \mu \mathrm{g})$, and Tetracyclines $(25 \mu \mathrm{g})$. For the Gram positive organisms, Erythromycin $(5 \mu \mathrm{g})$, Gentamicin $(10 \mu \mathrm{g})$, Augmentin $(30 \mu \mathrm{g})$, Streptomycin $(10 \mu \mathrm{g})$, Tetracycline $(10 \mu \mathrm{g})$, Chloramphenicol $(10 \mu \mathrm{g})$, Cloxacillin $(5 \mu \mathrm{g})$ and Cotrimoxazole $(25 \mu \mathrm{g})$. The zone of inhibition was then measured and recorded according to the Clinical and Laboratory Standard Institute [20]. The tests were done in duplicate to ensure reliability [21]. 


\subsection{Growth Characteristics of the Bacterial Isolates on Different Sugars}

The test was done to identify organisms that can grow and utilize 2 sugars (glucose and sucrose) to determine if the organisms can ferment the sugars. Sugar solution was prepared according to the manufacturer's procedure and $5 \mathrm{ml}$ was dispensed into test tube with durham tubes. The prepared solution was inoculated with the organisms and incubated at $37^{\circ} \mathrm{C}$ for $24-72 \mathrm{~h}$. Pale yellow indicated positive, negative no colour change was observed and gas production in the durham tubes also indicated a positive result.

\subsection{Antagonistic Effect of Bacterial Isolates against the Test Fungi and Pseudomonas sp.}

Each bacterial isolate was streaked on already prepared PDA plate and fungal plug was placed $23 \mathrm{~mm}$ away from the bacterial isolates in duplicates. The plates were then incubated at $25^{\circ} \mathrm{C}$ for $1-7$ days. Petri dishes inoculated with a fungus only were used as control treatment Antagonistic effect was determined according to Kucuk and Kivanc [22]. For Pseudomonas sp. a perpendicular streak was made.

\subsection{Effect of Fungicide on the Selected Fungi}

The test was done to identify organisms that can grow in the presence of the selected fungicide. The medium, PDA was prepared according to manufacturer's procedure and $0.01 \mathrm{~g}, 0.02 \mathrm{~g}$ and $0.03 \mathrm{~g}$ of the fungicide was added to the media. The poisoned medium was then inoculated with the fungal plugs and incubated at $25^{\circ} \mathrm{C}$ respectively (Ogunmefun et al., 2015).

Growth on the media indicates that the organisms can survive in the presence of the fungicide.

\section{Results}

\subsection{Growth Responses of the Bacterial Isolates to Different Environmental Parameters}

The growth response of the bacterial isolates from maize plants to $\mathrm{NaCl}$ and temperature is represented in Table 1. Maximum growth was observed at $1 \%$, followed by $2 \%$ and at $3 \%$ there was a reduction in growth. Growth response of the bacterial isolates from maize plants to different $\mathrm{pH}$ grown in nutrient broths is represented in Table 2. There was a progressive increase in the absorbance from $\mathrm{pH} 2$ to 8. It was also observed that least growth was obtained from Catabaterhongkongensis 1 at $\mathrm{pH} 2$ while the highest was Rhodococcusequi 1. Also there was reduction in the absorbance at $\mathrm{pH} 10$ except Vibrio fluvialis.

\subsection{Susceptibility Pattern of the Bacterial Isolates to Antibiotics}

The antibacterial susceptibility of gram negative and gram positive bacterial are represented in Table 3 and Table 4 respectively. It was observed that all gram 
Table 1. Qualitative growth response of bacterial isolates from maize plants to $\mathrm{NaCl}$ and temperature.

\begin{tabular}{|c|c|c|c|c|c|c|c|}
\hline \multirow{2}{*}{$\begin{array}{c}\text { Bacterial } \\
\text { isolates }\end{array}$} & \multicolumn{3}{|c|}{ Growth on $\mathrm{NaCl}$} & \multicolumn{4}{|c|}{ Temperature $\left({ }^{\circ} \mathrm{C}\right)$} \\
\hline & 1 & 2 & 3 & 4 & 25 & 37 & 50 \\
\hline Catabaterhongkongensis 1 & + & + & + & - & + & + & - \\
\hline Anaerococcustetradius & + & + & + & + & + & + & - \\
\hline Staphylococcus aureus 1 & + & - & - & + & + & + & + \\
\hline Corynebacterium argentoratense & + & + & + & - & + & + & - \\
\hline Clostridium clostridiforme & + & + & + & + & + & + & - \\
\hline Alistipeindistinctus & + & + & + & + & + & + & + \\
\hline Proteus vulgaris & + & + & + & + & + & + & + \\
\hline Pseudomonas aeruginosa & + & - & - & + & + & + & + \\
\hline Leifsonia aquatic & + & + & + & + & + & + & - \\
\hline Kurthiazopfu & + & + & + & - & + & + & - \\
\hline Morganellamorganic & + & + & + & + & + & + & + \\
\hline Rhodococcusequil & + & - & - & - & + & + & - \\
\hline Bacillus subtilis & + & - & - & + & + & + & + \\
\hline Catabaterhongkongensis 2 & + & + & + & + & + & + & + \\
\hline Brevibacteriumotitidis & + & - & - & + & + & + & + \\
\hline Rhodococcusequi 2 & + & - & - & + & + & + & - \\
\hline Lactobacillus coleohominis & + & + & + & + & + & + & + \\
\hline Staphylococcus aureus 2 & + & + & + & + & + & + & + \\
\hline Rhodococcusequi 3 & + & + & + & + & + & + & - \\
\hline Propionibacterium acnes & + & + & + & + & + & + & - \\
\hline Neisseria oralis & + & + & + & + & + & + & + \\
\hline Catenibacteriummitsuokai & + & + & + & - & + & + & + \\
\hline Legionella pnuemophila & + & + & + & + & + & + & - \\
\hline Vibrio fluvialis & + & + & + & + & + & + & + \\
\hline
\end{tabular}

Keys: $+=$ positive, $-=$ negative.

positive organisms showed more than $50 \%$ resistance to the antibiotics used except Gentamycin (31.25\%) and Streptomocin (50\%) (Table 3). More than 50\% of the Gram negative bacteria showed $100 \%$ resistance to the antibiotics tested. Generally. Alistipesindistinctus, Proteus vulgaris and Vibrio fluvialis were resistant to all the antibiotics (Table 4).

\subsection{Antagonistic Activities of the Bacterial Isolates against the Selected Fungi}

None of bacterial isolates had any antagonistic effect on fungi. Both organisms on the plates grew simultaneously without interfering with each other. However, there was reduction in the mycelia growth of the fungi in the presence of fungicide compared to when cultured on only PDA plate. 
Table 2. Comparative growth response of bacterial isolates from maize plants to different $\mathrm{pH}$ grown in nutrient broths.

\begin{tabular}{|c|c|c|c|c|c|}
\hline \multirow{2}{*}{$\begin{array}{l}\text { Bacterial } \\
\text { isolates }\end{array}$} & \multicolumn{5}{|c|}{$\mathrm{pH}$ range } \\
\hline & 2 & 4 & 6 & 8 & 10 \\
\hline Catabaterhongkongensis 1 & 0.42 & 0.58 & 1.51 & 1.51 & 0.70 \\
\hline Anaerococcustetradius & 0.67 & 0.95 & 1.42 & 1.47 & 0.78 \\
\hline Staphylococcus aureus 1 & 0.52 & 0.97 & 1.37 & 1.49 & 0.75 \\
\hline Corynebacterium argentoratense & 0.60 & 1.48 & 1.31 & 1.50 & 0.70 \\
\hline Clostridium clostridiforme & 0.78 & 0.52 & 1.45 & 1.27 & 0.53 \\
\hline Alistipeindistinctus & 0.62 & 1.42 & 1.51 & 1.50 & 1.41 \\
\hline Proteus vulgaris & 0.67 & 1.45 & 1.51 & 1.51 & 1.33 \\
\hline Pseudomonas aeruginosa & 0.57 & 0.90 & 1.29 & 1.49 & 0.65 \\
\hline Leifsonia aquatic & 0.67 & 0.54 & 1.47 & 1.51 & 0.47 \\
\hline Kurthiazopfu & 0.53 & 0.54 & 1.50 & 1.50 & 0.54 \\
\hline Morganellamorganic & 0.69 & 1.13 & 1.51 & 1.52 & 0.55 \\
\hline Rhodococcusequi 1 & 0.93 & 0.52 & 1.36 & 1.46 & 0.54 \\
\hline Bacillus subtilis & 0.57 & 0.55 & 1.51 & 1.33 & 0.70 \\
\hline Catabaterhongkongensis 2 & 0.57 & 0.61 & 1.51 & 1.50 & 0.47 \\
\hline Brevibacteriumotitidis & 0.55 & 0.58 & 1.30 & 1.50 & 0.77 \\
\hline Rhodococcusequi2 & 0.58 & 0.53 & 1.28 & 1.00 & 0.54 \\
\hline Lactobacillus coleohominis & 0.58 & 0.64 & 1.34 & 1.26 & 0.48 \\
\hline Staphylococcus aureus 2 & 0.58 & 0.56 & 1.48 & 1.45 & 0.98 \\
\hline Rhodococcusequi3 & 0.49 & 0.54 & 1.35 & 1.24 & 0.63 \\
\hline Propionibacterium acnes & 0.57 & 0.73 & 1.21 & 1.25 & 0.86 \\
\hline Neisseria oralis & 0.71 & 0.69 & 1.48 & 1.50 & 1.23 \\
\hline Catenibacteriummitsuokai & 0.53 & 0.55 & 1.32 & 1.48 & 0.72 \\
\hline Legionella pnuemophila & 0.52 & 0.60 & 1.49 & 1.52 & 0.47 \\
\hline Vibrio fluvialis & 0.72 & 0.75 & 1.50 & 1.51 & 1.40 \\
\hline
\end{tabular}

\section{Discussion}

Bacterial diversity is of particular importance in human sustenance since they comprise the majority of earth's species. It is also considered as one of the most useful resources with considerable significance in bioremediation and bioprospecting [23].

In this study, different parameters were put into consideration such as responses to different $\mathrm{pH}$, temperature and $\mathrm{NaCl}$. Environmental factors may influence plant pathogens, biocontrol agents and the mechanisms of their interactions [24]. All the twenty four bacterial species were found to be mesophiles as they grew at a maximum temperature of $37^{\circ} \mathrm{C}$. Thirteen of the isolates grew at $50^{\circ} \mathrm{C}$ which show that they were thermophiles. Similar observations were made by Javed et al. [25]. Bacillus spp. have been shown to live and survive in inhospitable environments including hot springs [26] [27]. 
Table 3. Antibiotic susceptibility patterns of selected Gram positive bacteria to antibiotics.

\begin{tabular}{|c|c|c|c|c|c|c|c|c|}
\hline Organisms & 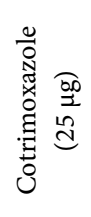 & 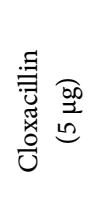 & 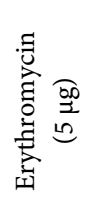 & 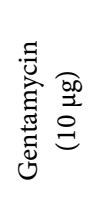 & 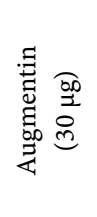 & 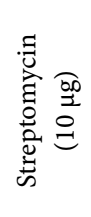 & 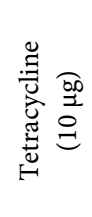 & 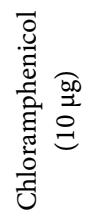 \\
\hline Catabaterhongkongensis 1 & $21(\mathrm{~S})$ & $0(\mathrm{R})$ & $0(\mathrm{R})$ & $0(\mathrm{R})$ & $0(\mathrm{R})$ & $0(\mathrm{R})$ & $0(\mathrm{R})$ & $0(\mathrm{R})$ \\
\hline Anaerococcustetradius & $15(\mathrm{I})$ & $0(\mathrm{R})$ & $0(\mathrm{R})$ & $20(S)$ & $0(\mathrm{R})$ & $20(S)$ & $13(\mathrm{R})$ & $16(S)$ \\
\hline Staphylococcus aureus 1 & $0(\mathrm{R})$ & $0(\mathrm{R})$ & $0(\mathrm{R})$ & $0(\mathrm{R})$ & $0(\mathrm{R})$ & $0(\mathrm{R})$ & $0(\mathrm{R})$ & $0(\mathrm{R})$ \\
\hline $\begin{array}{l}\text { Corynebacterium } \\
\text { argentoratense }\end{array}$ & $46(S)$ & $23(\mathrm{~S})$ & $19(\mathrm{~S})$ & $13(\mathrm{I})$ & $16(S)$ & $20(\mathrm{~S})$ & $23(S)$ & $14(\mathrm{I})$ \\
\hline Leifsonia aquatic & $0(\mathrm{R})$ & $0(\mathrm{R})$ & $0(\mathrm{R})$ & $19(S)$ & $0(\mathrm{R})$ & $0(\mathrm{R})$ & $0(\mathrm{R})$ & $0(\mathrm{R})$ \\
\hline Kurthiazopfu & $0(\mathrm{R})$ & $0(\mathrm{R})$ & $0(\mathrm{R})$ & $19(S)$ & $0(\mathrm{R})$ & $18(\mathrm{~S})$ & $0(\mathrm{R})$ & $15(\mathrm{I})$ \\
\hline Rhodococcus equi 1 & $0(\mathrm{R})$ & $0(\mathrm{R})$ & $0(\mathrm{R})$ & $0(\mathrm{R})$ & $0(\mathrm{R})$ & $0(\mathrm{R})$ & $0(\mathrm{R})$ & $0(\mathrm{R})$ \\
\hline Bacillus subtilis & $41(\mathrm{~S})$ & $0(\mathrm{R})$ & $11(\mathrm{R})$ & $29(S)$ & $0(\mathrm{R})$ & $19(\mathrm{~S})$ & $0(\mathrm{R})$ & $0(\mathrm{R})$ \\
\hline Catabacterhongkongensis 2 & $46(S)$ & $0(\mathrm{R})$ & $0(\mathrm{R})$ & $20(S)$ & $0(\mathrm{R})$ & $16(S)$ & $15(\mathrm{I})$ & $0(\mathrm{R})$ \\
\hline Brevibacteriumotitidis & $0(\mathrm{R})$ & $0(\mathrm{R})$ & $0(\mathrm{R})$ & $22(S)$ & $0(\mathrm{R})$ & $14(\mathrm{I})$ & $0(\mathrm{R})$ & $33(S)$ \\
\hline Rhodococcusequi 2 & $0(\mathrm{R})$ & $0(\mathrm{R})$ & $0(\mathrm{R})$ & $18(\mathrm{~S})$ & $0(\mathrm{R})$ & $21(\mathrm{~S})$ & $0(\mathrm{R})$ & $29(S)$ \\
\hline Lactobacillus coleohominis & $26(S)$ & $0(\mathrm{R})$ & $18(S)$ & $30(\mathrm{~S})$ & $0(\mathrm{R})$ & $26(S)$ & $18(S)$ & $20(S)$ \\
\hline Staphylococcus aureus 2 & $20(\mathrm{~S})$ & $0(\mathrm{R})$ & $0(\mathrm{R})$ & $24(\mathrm{~S})$ & $0(\mathrm{R})$ & $11(\mathrm{R})$ & $14(\mathrm{I})$ & $18(S)$ \\
\hline Rhodococcusequi 3 & $0(\mathrm{R})$ & $0(\mathrm{R})$ & $0(\mathrm{R})$ & $0(\mathrm{R})$ & $0(\mathrm{R})$ & $0(\mathrm{R})$ & $0(\mathrm{R})$ & $0(\mathrm{R})$ \\
\hline Propionibacterium acnes & $16(S)$ & $18(S)$ & $25(S)$ & $28(S)$ & $32(\mathrm{~S})$ & $15(\mathrm{I})$ & $18(S)$ & $13(\mathrm{I})$ \\
\hline Catenibacteriummitsuiokai & $0(\mathrm{R})$ & $0(\mathrm{R})$ & $0(\mathrm{R})$ & $23(S)$ & $0(\mathrm{R})$ & $22(\mathrm{~S})$ & $0(\mathrm{R})$ & $33(S)$ \\
\hline Susceptibility (\%) & 43.75 & 12.57 & 18.75 & 68.75 & 12.50 & 50 & 18.75 & 37.5 \\
\hline Resistance (\%) & 56.25 & 87.43 & 81.25 & 31.25 & 87.50 & 50 & 81.25 & 62.5 \\
\hline
\end{tabular}

Key: I-Intermediate, S-Susceptible, R-Resistant.

All the isolates grew at $\mathrm{pH} 2,4,6,7,8$ while seventeen isolates grew at $\mathrm{pH} 10$, as opposed to the work of Javed et al. [25]. It was also observed that all the twenty four organisms grew $1 \% \mathrm{NaCl}$ concentration, whereas only eighteen organisms grew at $2 \% \mathrm{NaCl}$ concentration and seventeen organisms grew at $3 \%$ $\mathrm{NaCl}$ concentration. There was growth reduction at $2 \%$ and $3 \%$ concentration because they were halosensitive and couldn't tolerate high salinity. Jhala et al. [28] reported that endophytic bacteria can tolerate $\mathrm{NaCl}$ concentration up to $4 \%$.

All the isolates showed varying degrees of resistance to commercial antibiotics. Although $C$. equi 1 and 3 were obtained from different sources both of them were resistant to antibiotics. The highest degree of resistance was observed among the Gram negative bacteria investigated in this study. Similar observation was made by Osibote et al. [29]. Iroha et al. [30] opined that the problem of antibiotic resistance in microorganisms may be due to the natural resistance of definite species to certain antibiotics, the transfer of antibiotic resistance among species and the use of sub-therapeutic doses of antibiotics. 
Table 4. Antibiotic susceptibility patterns of selected Gram negative bacteria to antibiotics.

\begin{tabular}{|c|c|c|c|c|c|c|c|c|}
\hline 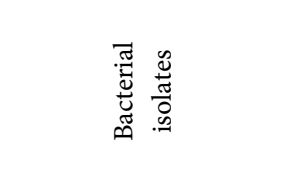 & 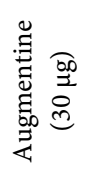 & 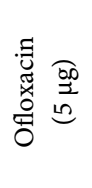 & 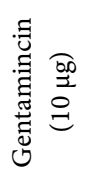 & 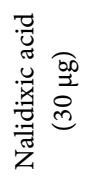 & 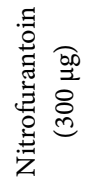 & 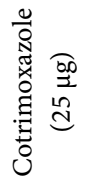 & 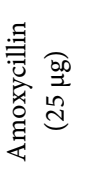 & 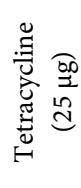 \\
\hline $\begin{array}{c}\text { Clostridium } \\
\text { clostridiforme }\end{array}$ & $0(\mathrm{R})$ & $23(S)$ & $0(\mathrm{R})$ & $28(\mathrm{~S})$ & $0(\mathrm{R})$ & $0(\mathrm{R})$ & $0(\mathrm{R})$ & $0(\mathrm{R})$ \\
\hline Alistipesindistinctus & $0(\mathrm{R})$ & $0(\mathrm{R})$ & $0(\mathrm{R})$ & $0(\mathrm{R})$ & $0(\mathrm{R})$ & $0(\mathrm{R})$ & $0(\mathrm{R})$ & $0(\mathrm{R})$ \\
\hline Proteus vulgaris & $0(\mathrm{R})$ & $0(\mathrm{R})$ & $0(\mathrm{R})$ & $0(\mathrm{R})$ & $0(\mathrm{R})$ & $0(\mathrm{R})$ & $0(\mathrm{R})$ & $0(\mathrm{R})$ \\
\hline $\begin{array}{c}\text { Pseudomonas } \\
\text { aeruginosa }\end{array}$ & $0(\mathrm{R})$ & $31(\mathrm{~S})$ & $0(\mathrm{R})$ & $25(\mathrm{~S})$ & $15(\mathrm{I})$ & $0(\mathrm{R})$ & $0(\mathrm{R})$ & $0(\mathrm{R})$ \\
\hline Morganellamorganic & $0(\mathrm{R})$ & $14(\mathrm{I})$ & $0(\mathrm{R})$ & $16(\mathrm{~S})$ & $0(\mathrm{R})$ & $0(\mathrm{R})$ & $0(\mathrm{R})$ & $0(\mathrm{R})$ \\
\hline Neisseria oralis & $0(\mathrm{R})$ & $16(\mathrm{~S})$ & $0(\mathrm{R})$ & $0(\mathrm{R})$ & $0(\mathrm{R})$ & $0(\mathrm{R})$ & $0(\mathrm{R})$ & $0(\mathrm{R})$ \\
\hline Legionella pneumophila & $0(\mathrm{R})$ & $22(\mathrm{~S})$ & $0(\mathrm{R})$ & $16(\mathrm{~S})$ & $11(\mathrm{R})$ & $0(\mathrm{R})$ & $0(\mathrm{R})$ & $0(\mathrm{R})$ \\
\hline Vibrio fluvialis & $0(\mathrm{R})$ & $15(\mathrm{I})$ & $0(\mathrm{R})$ & $0(\mathrm{R})$ & $0(\mathrm{R})$ & $0(\mathrm{R})$ & $0(\mathrm{R})$ & $0(\mathrm{R})$ \\
\hline Susceptibility (\%) & 0 & 37.5 & 0 & 50 & 0 & 0 & 0 & 0 \\
\hline Resistance (\%) & 100 & 62.5 & 100 & 50 & 100 & 100 & 100 & 100 \\
\hline
\end{tabular}

Key: I-Intermediate, S-Susceptible, R-Resistant.

The identification and characterization of microorganisms, useful as biocontrol agents or as producers of bioactive compounds, are of great relevance for the modern and ecocompatible agriculture [31]. Antibiosis often acts in concert with competition and/or parasitism [20]. The results of this investigation showed that none of the bacterial isolated were antagonistic to the fungal test pathogens tested at $25^{\circ} \mathrm{C}$ on PDA.

\section{Conclusion and Recommendation}

Although none of the bacterial isolates used in this study exhibited antagonistic effect against the isolated fungal pathogens, the isolates can be genetically modified to produce secondary metabolites that will result in biocontrol. Also, since some of the isolates were thermophilic, further work is therefore needed to test their antagonistic properties against the fungal pathogens at high temperature.

\section{Conflicts of Interest}

The authors declare no conflicts of interest regarding the publication of this paper.

\section{References}

[1] Kutama, A.S. (2012) Studies on the Epidemiology and Control of Sorghum Head and Loose Smuts in the Sudan Savanna Region of Nigeria. PhD Botany Thesis (Unpublished), 1-4.

[2] Fagwalawa, L.D., Kutama, A.S. and Yakasai, M.T. (2013) Current Issues in Plant Disease Control: Biotechnology and Plant Disease. Bayero Journal of Pure and Applied Sciences, 6, 121-126. https://doi.org/10.4314/bajopas.v6i2.26 
[3] Kumar, S. (2014) Plant Disease Management in India. Advances and Challenges. African Journal of Agricultural Research, 9, 1207-1217. https://doi.org/10.5897/AJAR2014.7311

[4] Kutama, A.S., Emechebe, A.M. and Aliyu, B.S. (2011) Evaluating the Efficacy of Seed Treatment Fungicides in the Control of Sorghum Head Smut Caused by Sporisoriumreilianum, in the Sudan Savanna Region of Nigeria. Journal of Phytopathology and Plant Health, 1, 93-98.

[5] Kutama, A.S., Emechebe, A.M. and Aliyu, B.S. (2011) Field Evaluation of Some Inoculation Techniques on the Incidence and Severity of Sorghum Head Smut (Sporisoriumreilianum) in Nigerian Sudan Savanna. Biological and Environmental Sciences Journal for the Tropics, 8, 292-296.

[6] Mark, G.L., Morrisey, J.P., Higgini, P. and O’Gara, F. (2006) Molecular Based Strategies to Exploit Pseudomonas Biocontrol Strains for Environmental Biotechnology Application. FEMS Microbiology Ecology, 56, 167-177.

https://doi.org/10.1111/j.1574-6941.2006.00056.x

[7] Landa, B.B., Navas-Cortes, J.A. and Jimenez-Diaz, R. (2004) Influence of Temperature on Plant-Rhizobacteria Interactions Related to Biocontrol Potential for Suppression of Fusarium Wilt of Chickpea. Plant Pathology, 53, 341-352.

https://doi.org/10.1111/j.0032-0862.2004.01008.x

[8] Gnanimanicakam, S. (Ed.) (2007) Plant-Associated Bacteria. Springer, New York.

[9] Chin-A-Woeng, T.F.C., Thomas-Oates, J.E., Lugtenberg, B.J.J. and Bloemberg, G.V. (2001) Introduction of the phzH Gene of Pseudomonas chlororaphis PCL1391 Extends the Range of Biocontrol Ability of Phenazine-1-Carboxylic Acid-Producing Pseudomonas spp. Strains. Molecular Plant-Microbe Interactions, 14, 1006-1015. https://doi.org/10.1094/MPMI.2001.14.8.1006

[10] Raaijmakers, J.M., Vlami, M. and de Souza, J.T. (2002) Antibiotic Production by Bacterial Biocontrol Agents. Antonie van Leeuwenhoek, 81, 537-547. https://doi.org/10.1023/A:1020501420831

[11] Silva, F.S.A., Romerio, R.D.S., Macagnan, D., Halfeld-Vieira, B.D.A., Pereira, M.C.B. and Mounteer, A. (2004) Rhizobacterial Induction of Systemic Resistance in Tomato Plants: Non-Specific Protection and Increase in Enzyme Activities. Biological Control, 29, 288-295. https://doi.org/10.1016/S1049-9644(03)00163-4

[12] Ji, P., Campbell, H.I., Kloepper, J.W., Jones, J.B., Suslow, T.V. and Wilson, M. (2006) Integrated Biological Control of Bacterial Speck and Spot of Tomato under Field Conditions Using Foliar Biocontrol Agents and Plant Growth Promoting Rhizobacteria. Biological Control, 36, 358-367. https://doi.org/10.1016/j.biocontrol.2005.09.003

[13] Foldes, T., Banhegye, I., Herpai, Z., Varga, L. and Szigeti, J. (2000) Isolation of Bacillus Strain from the Rhizosphere of Cereals and in Vitro Screening for Antagonism Against Phytopathogenic Food Borne and Spoilage Microorganisms. Journal of Applied Microbiology, 89, 840-846. https://doi.org/10.1046/j.1365-2672.2000.01184.x

[14] McSpadden, G.B. and Fravel, D. (2002) Biological Control of Plant Pathogens. Research Commercialization and Application in the USA. Plant Health Progress, 3, 17. https://doi.org/10.1094/php-2002-0510-01-rv

[15] Tabbene, O., Ben, S.I., Bouabdallah, F., Mangoni, M.L., Urdaci, M.C. and Limam, F. (2009) Production of Anti-Methicillin-Resistant Staphylococcus Activity from Bacillus subtilis sp. Strain B38 Newly Isolated from Soil. Applied Biochemistry and Biotechnology, 157, 407-419. https://doi.org/10.1007/s12010-008-8277-1 
[16] Todorova, S. and Kozhuharova, L. (2010) Characteristics and Antimicrobial Activity of Bacillus subtilis Strains Isolated from Soil. World Journal of Microbiology, 26, 1207-1216. https://doi.org/10.1007/s11274-009-0290-1

[17] Dinu, S., Sicuia, O., Constantinescu, F. and Fendrihan, S. (2016) Assessment of Some Abiotic Factors nn Microbial Bioproducts Useful in Biocontrol of Phytopathogens. Journal of Advances in Agriculture, 5, 799-803. https://doi.org/10.24297/jaa.v5i3.5052

[18] Cheesbrough, M. (2011) Distinct Laboratory Practical in Tropical Countries. Cambridge University Press, Cambridge, 136-140.

[19] Ekundayo, E.A., Adebisi, K., Boboye, B.E., Akinyele, B.J. and Adetuyi, F.C. (2015) Optimization of Culture Conditions for the Antagonistic Activities of Trichoderma viride against Sclerotiumrolfsii Causative Agent of Southern Blight Disease of Tomato. Malaysian Journal of Microbiology, 11, 240-245.

[20] Wafaa, A., Helmy, E., Hassan, A., Nefisa, M.A. and EL-Shayeb (2007) Biological and Antimicrobial Activities of Aqueous Extracts from Neem Tree (Azadirachtaindica A. Juss., Meliaceae). Journal of Application Science Research, 3, 1050-1055.

[21] Yilmaz, M., Soran, H. and Beyatli, Y. (2006) Antimicrobial Activities of Some Bacillus spp. Strains Isolated from the Soil. Microbiological Research, 161, 127-131. https://doi.org/10.1016/j.micres.2005.07.001

[22] Kucuk, C. and Kivanc, M. (2003) Isolation of Trichoderma spp. and Determination of Their Antifungal, Biochemical and Physiological Features. Turkish Journal of Biology, 22, 247-253.

[23] Homer-Devine, M.C., Carney, K.M. and Bohannan, B.J.M. (2004) An Ecological Perspective on Bacterial Biodiversity. Proceedings of Royal Society London Biological Sciences, 273, 113-122. https://doi.org/10.1098/rspb.2003.2549

[24] Gal-Hemed, I., Atanasova, L., Komon-Zelazowska, M., Irina, S., Druzhinina, I.S., Viterbo, A. and Yarden, O. (2011) Marine Isolates of Trichoderma spp. as Potential Hatolerant Agents of Biocontrol for Arid-Zone Agriculture. Applied and Environmental Microbiology, 77, 5100-5109. https://doi.org/10.1128/AEM.00541-11

[25] Javed, I.Q., Nausheen, Q. and Arjumand, S.B. (2009) Isolation of Antifungal Bacteria from Soil Samples. Mycopathology, 7, 5-10.

[26] Joseph, S.J., Hugenholtz, P., Sangwan, P., Osborne, C.A. and Janssen, P.H. (2010) Laboratory Cultivation of Widespread and Previously Uncultured Soil Bacteria. Applied and Environmental Microbiology, 69, 7210-7215. https://doi.org/10.1128/AEM.69.12.7210-7215.2003

[27] Kellenberger, E.M.K. and Serafin, R. (2011) Exploring the Unknown. The Revolution of Microbiology Journal, 2, 5-7.

[28] Jhala, Y.K., Shelat, H.N., Vyas, R.V. and Panpatte, D.G. (2015) Biodiversity of Endorhizospheric Plant Growth Promoting Bacteria. Journal Biofertilizers and Biopesticides, 6,151.

[29] Osibote, I.A., Okiki, P.A., Ekundayo, E.A. and Adekunle, A.C. (2014) Prevalence of Multidrug Resistant Bacterial Isolates from Meat Processing Equipment and Abattoir Environment in Ado Ekiti. Advances in Biological Research, 8, 207-211.

[30] Iroha, I.R., Ugbo, E.C., Ilang, D.C., Oji, A.E. and Ayogu, T.E. (2011) Bacteria Contamination of Raw Meat Sold in Abakaliki, Ebonyi State Nigeria. Journal of Public Health and Epidemiology, 3, 49-53.

[31] Spadaro, D. and Gullino, M.L. (2005) Improving the Efficacy of Biocontrol Agents against Soilborne Pathogens. Crop Protection, 4, 601-613.

https://doi.org/10.1016/j.cropro.2004.11.003 